\title{
Diversity and distribution of epiphytic lichens on Cedrus atlantica and Quercus faginea in Mount Babor Forest, Algeria
}

\author{
AMINA BELGUIDOUM, TAKIA LOGRADA, MESSAOUD RAMDANI" \\ Laboratory for Valorization of Natural Biological Resources, SNV Faculty, Ferhat Abbas University Setif-1. El Bez, Setif 19000, Algeria. \\ Tel.: +213-658-101010, •email: ramdanimessaoud@yahoo.com
}

Manuscript received: 10 January 2020. Revision accepted: 19 January 2021.

\begin{abstract}
Belguidoum A, Lograda T, Ramdani M. 2021. Diversity and distribution of epiphytic lichens on Cedrus atlantica and Quercus faginea in Mount Babor Forest, Algeria. Biodiversitas 22: 887-899. Information about lichen diversity in Algeria is limited despite their important role as biological indicators of ecosystem health. The aim of the study was to carry out an inventory of epiphytic lichens in the Mount Babor Forest on two types of phorophytes (host trees), i.e., Cedrus atlantica and Quercus faginea, in varying altitudinal gradients and the diameter of host tree. The similarity of the sampled sites was assessed by the Sorensen index ( $\beta$ ). Sixty-six species of epiphytic lichens were identified, which belong to 24 families and 38 genera. $C$. atlantica hosted a higher number of species than $Q$. faginea. The majority of lichen on C. atlantica belonged to the Parmeliaceae family, whereas those on $Q$. faginea belonged to the Physciaceae family. Crustose and foliose lichens were the most common species in the study area. The results showed the existence of a distinct relationship between the parameters of the distribution (i.e., tree diameter, elevation) and the specific lichen richness. The greatest number of lichen species (59 species) was observed on large diameter trunks $(41-60 \mathrm{~cm})$. Lichen diversity increased along with the increase in altitude. Sorensen's similarity index revealed the presence of heterogeneity in the community composition of lichen vegetation.
\end{abstract}

Keywords: Algeria, biodiversity, Cedrus atlantica, epiphytic lichens, Mount Babor Forest, Quercus faginea

\section{INTRODUCTION}

Lichens play an important role in forest ecosystems. They provide food resources and refuges for other organisms and influence forest hydrology and nutrients cycling (Stapper and John 2015; Van Stan and Pypker 2015). However, lichens are unfamiliar to common people, and even for naturalists whose knowledge of species is imperfect. Despite there is an increasing trend in the discoveries of newly described lichens. They are subject to very strong anthropogenic pressure caused by industrialization, increased urbanization, and exploitation of forest areas, especially those in the Mediterranean forests, which are a fragile natural environment (Scheidegger and Goward 2002; Bricaud 2010; Root et al. 2015; Nardi et al. 2016; Lubek et al. 2018).

Because of their sensitivity to any changes in environmental conditions, lichens are often used as biological indicators of habitat change (Vondrák et al. 2018). Lichens are able to integrate the effects of different biotic and abiotic environmental factors. For example, analysis of their occurrence on forest stands provides guidance on media interference levels and the state of maturation of forest stands (Jonsson et al. 1999; Watt et al. 2007; Bergamini et al. 2009; Bricaud 2010).

Species richness, abundance, and distribution of lichens in an ecosystem can be used as a model to characterize the responses of lichens to environmental changes (Stofer et al. 2006; Pinho et al. 2012). Environmental factors, microclimatic changes, and habitat characteristics, such as age and diameter of trees and physical properties of bark, as well as altitude, influence significantly the growth and distribution of lichen species (Hedenas and Ericson 2000; Van Herk 2001; Radies and Coxson 2004). In some cases, the Sorensen similarity index has been used to compare the assessment of species from two populations (Sevgi et al. 2010; Sanogo and Kabre, 2014; Boni et al. 2015). This classic method of calculating this coefficient is widely used in ecological studies (Benítez et al. 2018; Vondrák et al. 2018).

Algeria is poorly explored from a lichenological perspective despite its vast area (i.e., 2,381,741 $\mathrm{km}^{2}$ ). Only few fragmentary and occasional floristic inventory studies have been devoted to it (Amrani et al. 2015). One of the most important biodiversity areas in the country is Mount Babor. The floristic diversity of the Mount Babor Forest is much more marked than that of most other regions of Algeria, because of its orographic and essentially climatic peculiarities. It is an area known for its natural landscapes and exceptionally rich biodiversity, rare and endemic species (Quézel and Santa 1962; Ledant et al. 1985; Bougaham et al. 2015, 2020; Bougaham and Rebbas 2020).

The aim of this study is to investigate the diversity and distribution of epiphytic lichens on two species of phorophytes (host trees), namely Cedrus atlantica and Quercus faginea in the Mount Babor Forest. We expect that the results of this study can enrich the checklist of lichens species in Algeria, and the Mediterranean region more broadly. 


\section{MATERIALS AND METHODS}

\section{Study area and period}

The study was conducted in the Mount Babor Forest during the period of March to November 2020. Mount Babor Forest is located in the southern part of the province of Setif, Algeria and lies between the latitudes $36^{\circ} 29^{\prime} 18^{\prime \prime}$ $36^{\circ} 19^{\prime} 05^{\prime \prime} \mathrm{N}$ and the longitudes $5^{\circ} 24^{\prime} 56^{\prime \prime}-5^{\circ} 30^{\prime} 46^{\prime} \mathrm{E}$ (Figure 1). The forest covers a total area of 1000 ha. The highest elevation of the study area is $2004 \mathrm{~m}$ above sea level (asl).

The lengthening of mountainous masses, perpendicular to the direction of the humid winds, favors the condensation of clouds on the northern slope, which receives $1190 \mathrm{~mm}$ of precipitation, while the southern slope receives only $717 \mathrm{~mm}$. The most intense precipitation occurs during the months of December through March. The average snowfall duration is 156 days/year (Gharzouli 2007). The climate of the region is continental with February being the coldest month of the year, while the hottest month is August. The minimum temperature is$3^{\circ} \mathrm{C}$ ), while the maximum is $28^{\circ} \mathrm{C}$.

The Babor forest ecosystem is dominated by cedar (Cedrus atlantica). This species is widely distributed especially on the north side of Mount Babor; the Cedrus is very dominant above $900 \mathrm{~m}$ asl. The vegetation below 800 $\mathrm{m}$ asl consists of Cedrus atlantica, Quercus ilex, Juniperus oxycedrus, Buxus sempervirens, Populus tremula, Acer campestre, Acer obtusatum and Quercus faginea accompanied with Abies numidica, species endemic to Mount Babor (Quézel and Santa 1962; Ledant et al. 1985; Gharzouli 2007).

\section{Sampling methods}

Specimens of epiphytic lichen living on Cedrus atlantica and Quercus faginea phorophytes were collected from 15 sampling sites in the Mount Babor Forest (Table 1). All samples were collected at a height of 0 to $2 \mathrm{~m}$ from the ground and around the trunk. The diameters of Cedrus atlantica phorophytes were grouped into five diameter classes: 0-20, 21-40, 41-60, 61-100 and over $100 \mathrm{~cm}$.

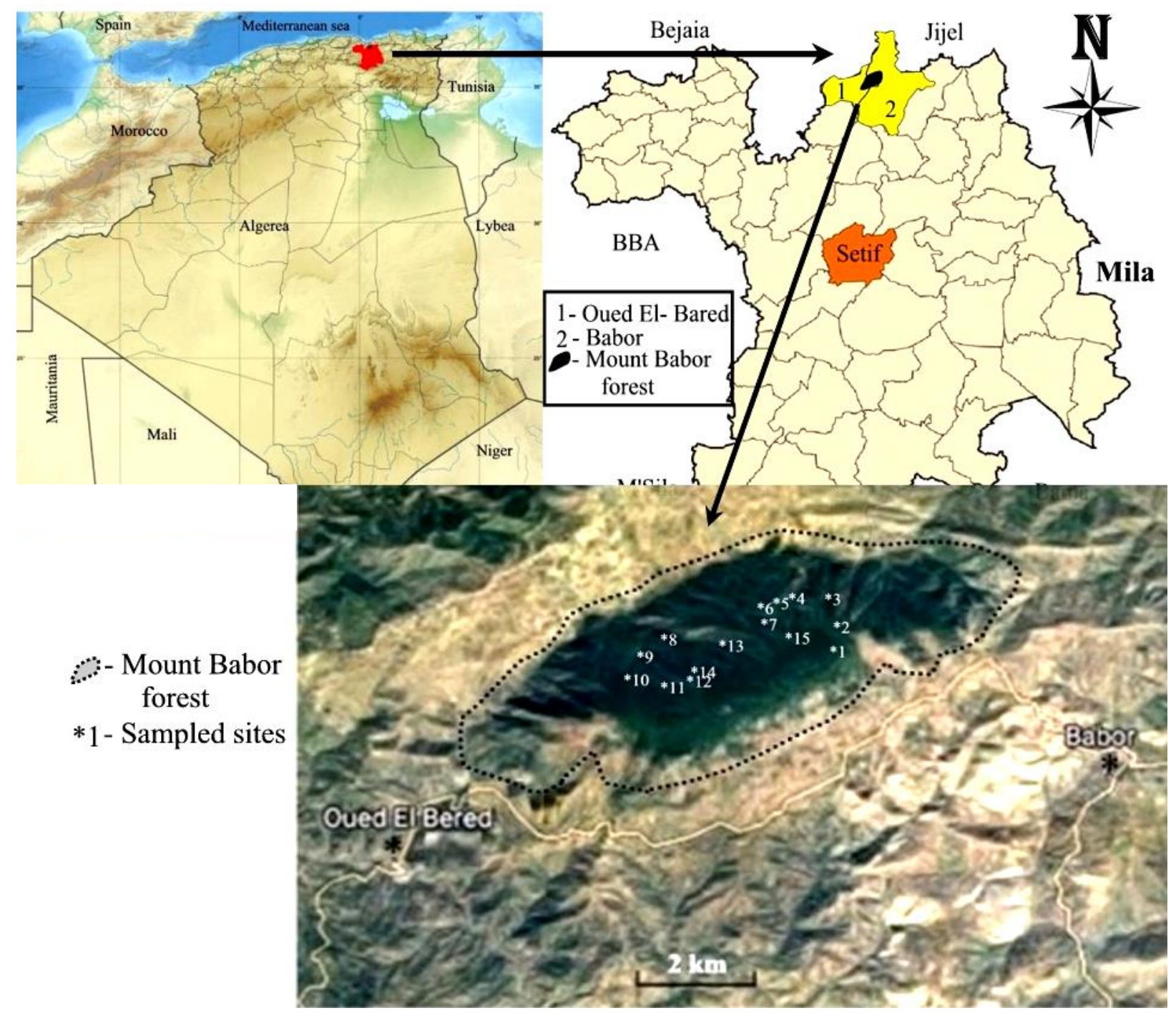

Figure 1. Location of the sampling sites in Mount Babor Forest, Setif Province, Algeria 
Table 1. Geographical coordinates of the sampled sites

\begin{tabular}{llrl}
\hline Sites & Geographical coordinates & $\begin{array}{r}\text { Alt. } \\
(\mathbf{m})\end{array}$ & Phorophytes \\
\hline 1 & $36^{\circ} 30^{\prime} 13^{\prime \prime} \mathrm{N} 5^{\circ} 29^{\prime} 08^{\prime \prime} \mathrm{E}$ & 1400 & C. atlantica \\
2 & $36^{\circ} 30^{\prime} 23^{\prime \prime} \mathrm{N} 5^{\circ} 29^{\prime} 09^{\prime \prime} \mathrm{E}$ & 1514 & \\
3 & $36^{\circ} 30^{\prime} 38^{\prime \prime} \mathrm{N} 5^{\circ} 28^{\prime} 38^{\prime \prime} \mathrm{E}$ & 1580 & \\
4 & $36^{\circ} 30^{\prime} 28^{\prime \prime} \mathrm{N} 5^{\circ} 28^{\prime} 28^{\prime \prime} \mathrm{E}$ & 1718 & \\
& & & \\
5 & $36^{\circ} 30^{\prime} 28^{\prime \prime} \mathrm{N} 5^{\circ} 28^{\prime} 22^{\prime \prime} \mathrm{E}$ & 1778 & C. atlantica and \\
6 & $36^{\circ} 30^{\prime} 40^{\prime \prime} \mathrm{N} 5^{\circ} 28^{\prime} 28^{\prime \prime} \mathrm{E}$ & 1790 & Q. faginea \\
7 & $36^{\circ} 30^{\prime} 33^{\prime \prime} \mathrm{N} 5^{\circ} 28^{\prime} 24^{\prime \prime} \mathrm{E}$ & 1812 & \\
8 & $36^{\circ} 30^{\prime} 10^{\prime \prime} \mathrm{N} 5^{\circ} 26^{\prime} 37^{\prime \prime} \mathrm{E}$ & 1868 & \\
9 & $36^{\circ} 30^{\prime} 10^{\prime \prime} \mathrm{N} 5^{\circ} 26^{\prime} 40^{\prime \prime} \mathrm{E}$ & 1900 & \\
10 & $36^{\circ} 30^{\prime} 10^{\prime \prime} \mathrm{N} 5^{\circ} 26^{\prime} 19^{\prime \prime} \mathrm{E}$ & 1930 & \\
11 & $36^{\circ} 30^{\prime} 05^{\prime \prime} \mathrm{N} 5^{\circ} 26^{\prime} 35^{\prime \prime} \mathrm{E}$ & 1940 & \\
12 & $36^{\circ} 30^{\prime} 08^{\prime \prime} \mathrm{N} 5^{\circ} 27^{\prime} 17^{\prime \prime} \mathrm{E}$ & 1948 & \\
13 & $36^{\circ} 30^{\prime} 15^{\prime \prime} \mathrm{N} 5^{\circ} 27^{\prime} 40^{\prime \prime} \mathrm{E}$ & 1952 & \\
14 & $36^{\circ} 30^{\prime} 10^{\prime \prime} \mathrm{N} 5^{\circ} 27^{\prime} 22^{\prime \prime} \mathrm{E}$ & 1950 & \\
15 & $36^{\circ} 30^{\prime} 15^{\prime \prime} \mathrm{N} 5^{\circ} 28^{\prime} 38^{\prime \prime} \mathrm{E}$ & 1774 & \\
& & & \\
\hline
\end{tabular}

\section{Lichens identification}

The lichen materials were observed in detail using a binocular (Optika) and an optical microscope (Aksioscop 40, Zeiss; magnification: 40X), using spot tests with chemicals. The identification of the lichens was based on references from several books, including Ozenda and Clauzade (1970); Boistel (1986); Tiévant (2001); Jans (2011); Van Haluwyn et al. (2013), and websites, such as French Association of Lichenology (http://www.afllichenologie.fr), LIAS light - A Database for Rapid Identification of Lichens (http://liaslight.lias.net/) and the British Lichen Society (https:/www.britishlichensociety.org.uk/). Specimens of the identified lichens have been preserved in the herbarium of the VRBN Laboratory of the Faculty of Nature and Life Sciences of Ferhat Abbas University, Algeria.

\section{Calculation of the Sorensen Index}

The Sorensen index $(\beta)$ measures the similarity between species from two sites (Sorensen 1948; Whittaker 1960). It is based on the following formula:

$$
\beta=2 C /(S 1+S 2)
$$

Where;

$\mathrm{C}$ : Number of common species between two sites

$\mathrm{S} 1$ : Number of species for site 1

S2: Number of species for site 2

The Sorensen index ranges from zero (no common species between two sites); to one (all species from site 1 exist in site 2).

\section{RESULTS AND DISCUSSION}

\section{Species richness}

The inventory of lichen species on two phorophytes (Cedrus atlantica and Quercus faginea) at the 15 sites in the Mount Babor Forest resulted in 66 species of epiphytic lichens (Table 2). Species richness of the lichens on the two types of phorophytes was different with a larger number of lichen species were found on Cedrus atlantica, which was the dominant species in the region. Some species were present in all stations including Pleurosticta acetabulum, Pseudevernia furfuracea, Parmelina pastillifera, Pertusaria amara, Lecanora alpigena, Anaptychia ciliaris, and Lecanora argentata, suggesting that they are generalist species adapted to wide range of ecological conditions. Many nitrophilic species from the genera of Caloplaca, Physcia, and Xanthoria were present. These species disappear during the closure and aging of the afforestation.

\section{Physiognomic forms}

All physiognomic forms of the lichens were represented in the study area (Figure 2). A clear dominance of crustacean thalli was to be noted in which $60 \%$ of the morphological forms were found on C. atlantica and 64\% were found on $Q$. faginea. The foliose thalli were represented by $21 \%$ of species on $C$. atlantica and $15 \%$ on $Q$. faginea. On the other hand, the complex and fruticose thalli were the least represented in the study area. As for the categories of squamulose, gelatinous and leper's thalli, they were poorly represented. The corticolous and lignicolous sampling carried out in the Mount Babor Forest showed that epiphytic lichens grew luxuriantly on $C$. atlantica than on $Q$. faginea.

The inventory of the lichens on $C$. atlantica allowed us to identify 62 species, belonging to 36 genera grouped into 23 families (Figure 3). Parmeliaceae revealed their dominance over the phorophyte $C$. atlantica with nine species, followed by Teloschistaceae and Lecanoraceae with seven species for each. The Physiaceae and Pertusariaceae families, were represented each one by six species, followed by Ochrolechiaceae with four species, while the rest of the families was represented by one or two lichen species.

On $Q$. faginea, 39 species of lichens were inventoried, belonging to 21 genera and 18 families (Figure 3). The Phlyctidaceae family, with eight species of lichens, was the richest in specific diversity, followed by Lecanoraceae $(5$ species) and Teloschistaceae with 4 species. The two families Cladoniaceae and Ochrolechiaceae were represented by three species for each one.

The systematic spectrum shows greater generic biodiversity on Cedrus atlantica than Quercus faginea (Figure 4). On C. atlantica, the genus Lecanora with seven lichen species was the richest in specific diversity, followed by the genus Caloplaca with 6 species, Ochrolechia with 4 species, and Physcia with 3 species, while the other 31 genera were represented by one or two species. However, the genera Phlyctis and Lecanora were represented by 5 lichen species each on $Q$. faginea, followed by the genus Caloplaca, with 4 species, Ochrolechia and Cladonia with 3 species and two species for each of the genera (Physconia, Pertusaria, and Acrocordia), while the 13 genera were represented by a single species. 
Table 2. Lichen species identified on two phorophytes (host trees) at 15 stations in Mount Babor Forest, Algeria

\begin{tabular}{|c|c|c|c|c|}
\hline \multirow{2}{*}{ Species } & \multirow{2}{*}{ Thalli } & \multicolumn{2}{|c|}{ Phorophyte } & \multirow{2}{*}{ Stations } \\
\hline & & 1 & 2 & \\
\hline Acrocordia conoidea (Fr.) Körb. & $\mathrm{Cr}$ & - & + & $\mathrm{S} 8, \mathrm{~S} 12, \mathrm{~S} 13, \mathrm{~S} 15$ \\
\hline Acrocordia punctata (Ach.) A. Massal. & $\mathrm{Cr}$ & + & + & S5-S7, S9-S15 \\
\hline Amandinea punctata (Hoffm.) Coppins \& Scheid & $\mathrm{Cr}$ & + & - & S5-S15 \\
\hline Anaptychia ciliaris (L.) Körb. Ex Massal. & Fr & + & + & S1-S15 \\
\hline Bacidia rubella (Hoffm.) Massal & $\mathrm{Cr}$ & + & + & S4-S11, S12-S15 \\
\hline Bryoria capillaris (Ach.) Brodo et Hawksw. & Fr & + & - & S4-S8 \\
\hline Bryoria fuscescens (Gyeln.) Brodo \& Hawksw. & $\mathrm{Fr}$ & + & - & S4-S11 \\
\hline Calicium viride Pers. & $\mathrm{Cr}$ & + & - & S5-S15 \\
\hline Caloplaca cerina (Ehrh. Ex Hedw.) Th. Fr. & $\mathrm{Cr}$ & + & - & S5-S12 \\
\hline Caloplaca ferruginea (Huds.) Th. Fr. & $\mathrm{Cr}$ & + & + & S5-S8, S12 \\
\hline Caloplaca flavorubescens (Huds.) Laundon & $\mathrm{Cr}$ & + & - & S3-S15 \\
\hline Caloplaca flavovirescens (Wulfen) D.T. \& Sarnth. & $\mathrm{Cr}$ & + & + & S3-S7, S12 \\
\hline Caloplaca inconnexa (Nyl.) Zahlbr. & $\mathrm{Cr}$ & + & + & S4-S11 \\
\hline Caloplaca suaedae o.l. Gilbert et Coppins & $\mathrm{Cr}$ & + & + & S4-S13 \\
\hline Candelariella reflexa (Nyl.) Lettau & $\mathrm{Cr}$ & + & + & S5-S15 \\
\hline Candelariella vitellina (Hoffm.) Müll. Arg. Chémo. & $\mathrm{Cr}$ & + & - & S4-S8, S10-S14 \\
\hline Chrysothrix flavovirens Tønsberg & Le & + & + & S5-S11, S13 \\
\hline Cladonia coniocraea (Flörke) Spreng. & Co & + & + & S1-S8, S12-S15 \\
\hline Cladonia fimbriata (L.) $\mathrm{Fr}$ & Co & - & + & S7, S8, S15 \\
\hline Cladonia symphycarpa (Flörke) Fr. & Co & - & + & S15 \\
\hline Cliostomum griffithii (Sm.) Hepp & $\mathrm{Cr}$ & - & + & $\mathrm{S} 7, \mathrm{~S} 8, \mathrm{~S} 12-\mathrm{S} 15$ \\
\hline Coenogonium luteum (Dicks.) Kalb et Lücking & $\mathrm{Cr}$ & + & - & $\mathrm{S} 5, \mathrm{~S} 10-\mathrm{S} 14$ \\
\hline Collema nigrescens (Huds.) Dc & $\mathrm{Ge}$ & + & - & $\mathrm{S} 5, \mathrm{~S} 10-\mathrm{S} 14$ \\
\hline Collema subflaccidum Degel. & $\mathrm{Ge}$ & - & + & S7, S8 \\
\hline Evernia prunastri (L.) Ach Chémo. & $\mathrm{Fr}$ & + & - & S4-S9 \\
\hline Flavoparmelia caperata (L.) Hale & Fo & + & - & $\mathrm{S} 1, \mathrm{~S} 5-\mathrm{S} 8, \mathrm{~S} 12-\mathrm{S} 15$ \\
\hline Heteroplacidium fusculum (Nyl.) G. et Roux & Fo & + & - & S5-S12, S14 \\
\hline Hypocenomyce scalaris (Ach.) M. Choisy & $\mathrm{Sq}$ & + & + & $\mathrm{S} 5, \mathrm{~S} 6, \mathrm{~S} 9-\mathrm{S} 15$ \\
\hline Hypogymnia tubulosa (Schaer.) Hav. & Fo & + & - & S6-S14 \\
\hline Imshaugia aleurites S.l.f. Meyer & Fo & + & - & $\mathrm{S} 1, \mathrm{~S} 3, \mathrm{~S} 6, \mathrm{~S} 13, \mathrm{~S} 14$ \\
\hline Lecanora allophana (Ach.) Nyl. & $\mathrm{Cr}$ & + & - & S2-S6, S9-S13 \\
\hline Lecanora alpigena (Ach.) Roux & $\mathrm{Cr}$ & + & + & $\mathrm{S} 1, \mathrm{~S} 3, \mathrm{~S} 5, \mathrm{~S} 6, \mathrm{~S} 9-\mathrm{S} 13, \mathrm{~S} 15$ \\
\hline Lecanora argentata (Ach.) Malm & $\mathrm{Cr}$ & + & + & S1-S15 \\
\hline Lecanora carpinea (L.) Vain. & $\mathrm{Cr}$ & + & + & S1-S4, S6, S7, S10-S14 \\
\hline Lecanora chlarotera Nyl. & $\mathrm{Cr}$ & + & + & $\mathrm{S} 1, \mathrm{~S} 3, \mathrm{~S} 5, \mathrm{~S} 6, \mathrm{~S} 9-\mathrm{S} 15$ \\
\hline Lecanora conizaeoides Nyl. Ex cromb. & $\mathrm{Cr}$ & + & + & S1-S6, S10-S15 \\
\hline Lecanora strobilina (Spreng.) Kieff. & $\mathrm{Cr}$ & + & - & S2-S15 \\
\hline Lecidella elaeochroma (Ach.) M. & $\mathrm{Cr}$ & + & + & S1-S3, S5-S14 \\
\hline Lepraria incana (L.) Ach & Le & + & - & S2, S3, S5-S15 \\
\hline Mycoblastus sanguinarius (L) Norman & $\mathrm{Cr}$ & + & + & S2-S13 \\
\hline Nephroma parile Ach. & Fo & + & - & S5-S15 \\
\hline Ochrolechia subviridis (Høeg) Erichsen & $\mathrm{Cr}$ & + & - & S2-S15 \\
\hline Ochrolechia tatarea (L.) Massal. & $\mathrm{Cr}$ & + & + & S2-S15 \\
\hline Ochrolechia turneri (Sm.) Hasselr. & $\mathrm{Cr}$ & + & + & S1-S3, S6-S14 \\
\hline Ochrolechia alboflavescens (Wulfen) Zahlbr. & $\mathrm{Cr}$ & + & + & S3-S15 \\
\hline Parmelia tiliacea (Hoffm.) Hale & Fo & + & - & S7, S15 \\
\hline Parmelina pastillifera Hharm.) Hale & Fo & + & - & S1-S15 \\
\hline Pertusaria amara (Ach.) Nyl. & $\mathrm{Cr}$ & + & + & S1-S15 \\
\hline Pertusaria flavida (Dc.) Laundon & $\mathrm{Cr}$ & + & - & S1-S8, S12-S15 \\
\hline Pertusaria hymenea (Ach.) Schaerer & $\mathrm{Cr}$ & + & - & S3-S7, S9-S15 \\
\hline Pertusaria mammosa Harm. & $\mathrm{Cr}$ & + & - & S4-S6, S9, S13-S15 \\
\hline Pertusaria pertusa (Weigel) Tuck. & $\mathrm{Cr}$ & + & + & S3-S15 \\
\hline Phlyctis agelaea (Ach.) Flot. & $\mathrm{Cr}$ & + & + & S3-S11 \\
\hline Phlyctis argena (Sprengel) Flotow & $\mathrm{Cr}$ & + & + & S3-S14 \\
\hline Physcia aipolia (Ehrh. Ex Humb.) Fürnrohe & Fo & + & + & S3-S11 \\
\hline Physcia leptalea (Ach.) Dc. & Fo & + & + & $\mathrm{S} 4, \mathrm{~S} 8$ \\
\hline Physcia tenella (Scop.) Dc & Fo & + & + & S3-S5, S9-S11 \\
\hline Physconia grisea (Lam.) Poelt & Fo & + & + & $\mathrm{S} 1, \mathrm{~S} 12$ \\
\hline Physconia venusta (Ach.) Poelt & Fo & + & + & S4-S8, S10-S12, S15 \\
\hline Pleurosticta acetabulum (Neck.) & Fo & + & + & S1-S15 \\
\hline Protoblastenia rupestris (Scop.) Steiner & $\mathrm{Cr}$ & + & + & $\mathrm{S} 2, \mathrm{~S} 4$ \\
\hline Pseudevernia furfuracea (L.) Zopf - Lég. & $\mathrm{Fr}$ & + & + & S1-S15 \\
\hline Ramalina farinacea (Hoffm.) & $\mathrm{Fr}$ & + & - & S7, S9, S10, S12 \\
\hline Tephromela atra (Wlld.) Vainio & $\mathrm{Cr}$ & + & + & $\mathrm{S} 1, \mathrm{~S} 4, \mathrm{~S} 5$ \\
\hline Varicellaria hemisphaerica (Flörke) & $\mathrm{Cr}$ & + & - & S1, S4, S12, S14, S15 \\
\hline Xanthoria parietina (L.) Th. Fr. & Fo & + & - & $\mathrm{S} 1, \mathrm{~S} 2$ \\
\hline
\end{tabular}

Note: Thallus (Cr: Crustose, Fr: Fruticose, Co: Complex, Fo: Foliose, Le: Lepers, Sq: Squamulose, Ge: Gelatinous); Phorophyte (1: $C$. atlantica, 2: Q. faginea; (+) Present, (-) Absent; Lichens images are assembled in Figure S1. 


\section{Diameter classes}

The distribution of lichens according to the diameter of the trees showed that a very low number of lichens occupied trees with a trunk diameter less than $20 \mathrm{~cm}$ (young trees) (Figure 5). The greatest number of lichens (59 species) was observed on medium diameter trunks (41$60 \mathrm{~cm}$ in diameter). The number of species decreased again when the tree diameter increases (on old trees with a diameter exceeding $100 \mathrm{~cm}$ ).

\section{Altitudinal gradient}

A close relationship between the altitudinal gradient and the number of epiphytic species on $C$. atlantica was detected (Figure 6). The increase in altitude had a positive relationship with the increase of the number of epiphytic species, confirmed by the regression curve. The highest richness was observed for an altitudinal range between 1750 and $1955 \mathrm{~m}$ asl. The smallest number of species, 19 species, was found at the lowest elevation which is $1400 \mathrm{~m}$ asl.
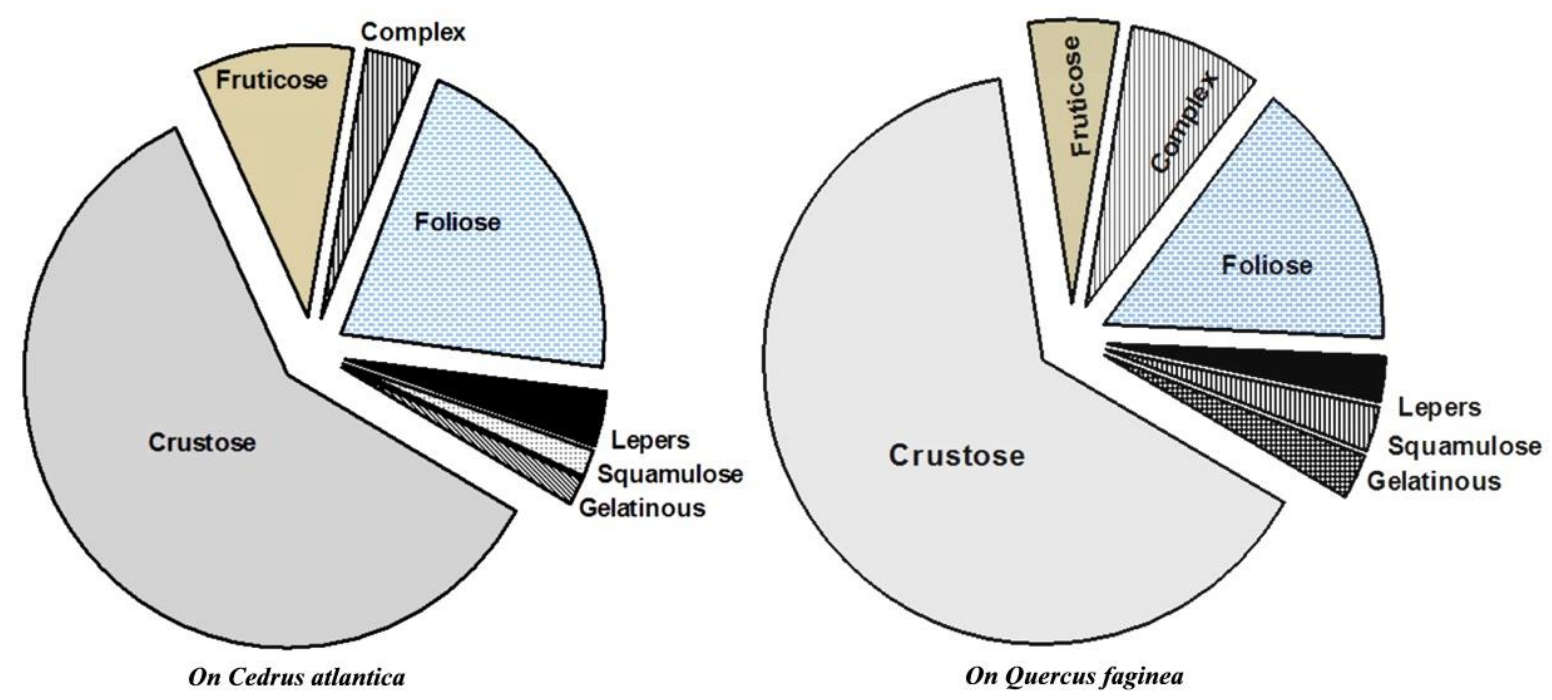

Figure 2. Morphological type of lichens on Cedrus atlantica and Quercus faginea

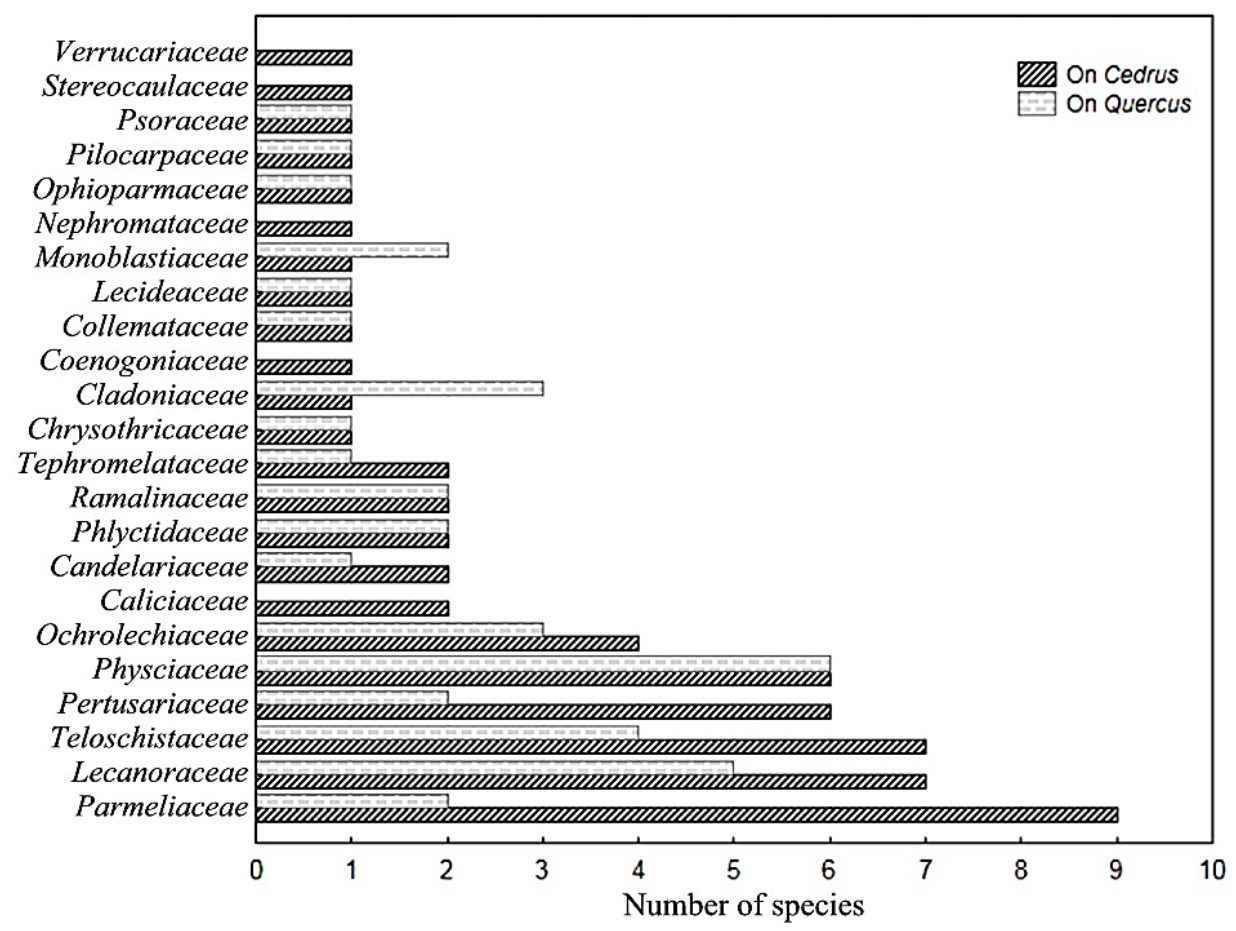

Figure 3. Number of species in each family identified on Cedrus atlantica and Quercus faginea 


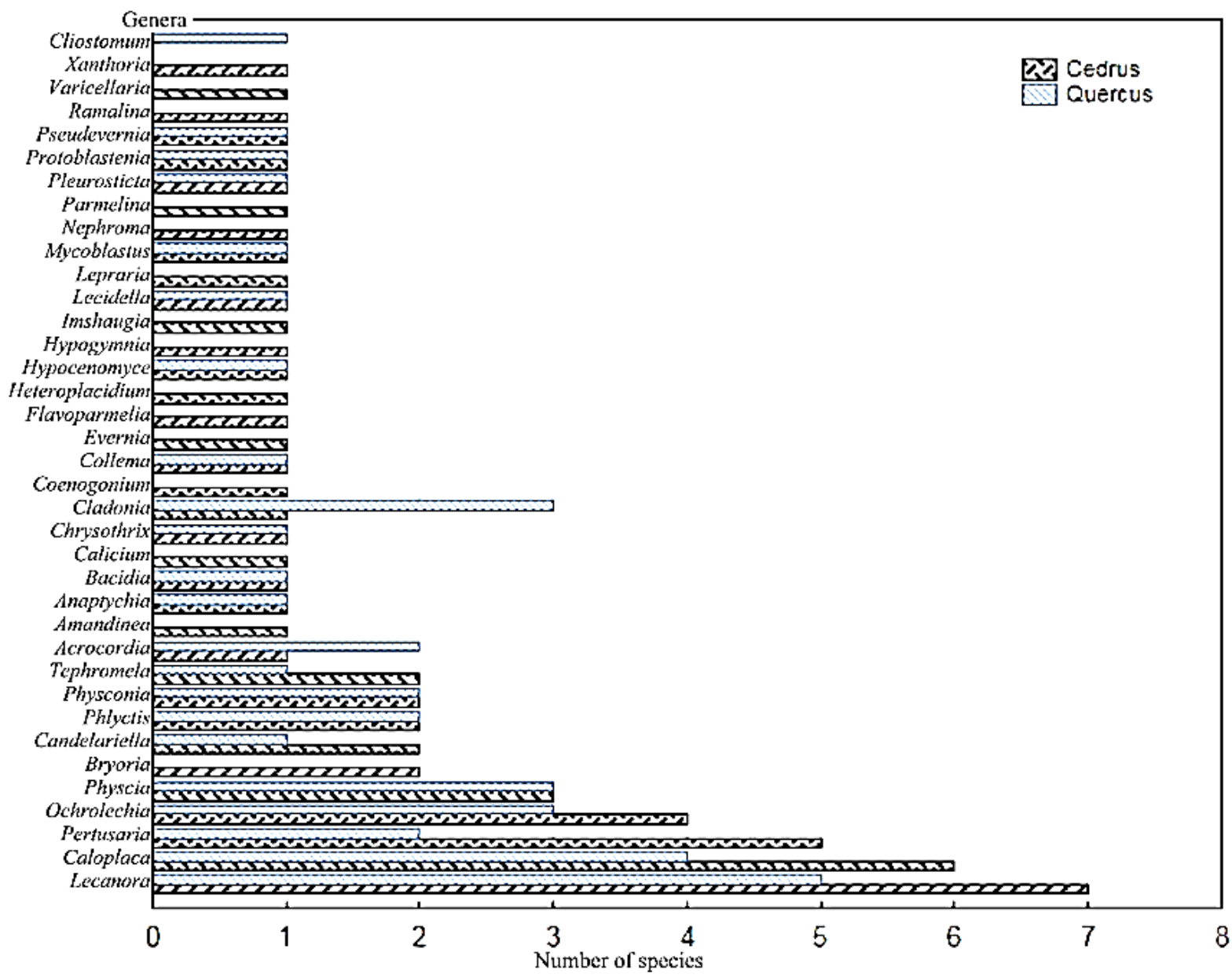

Figure 4. Number of species in each genus identified on Cedrus atlantica and Quercus faginea

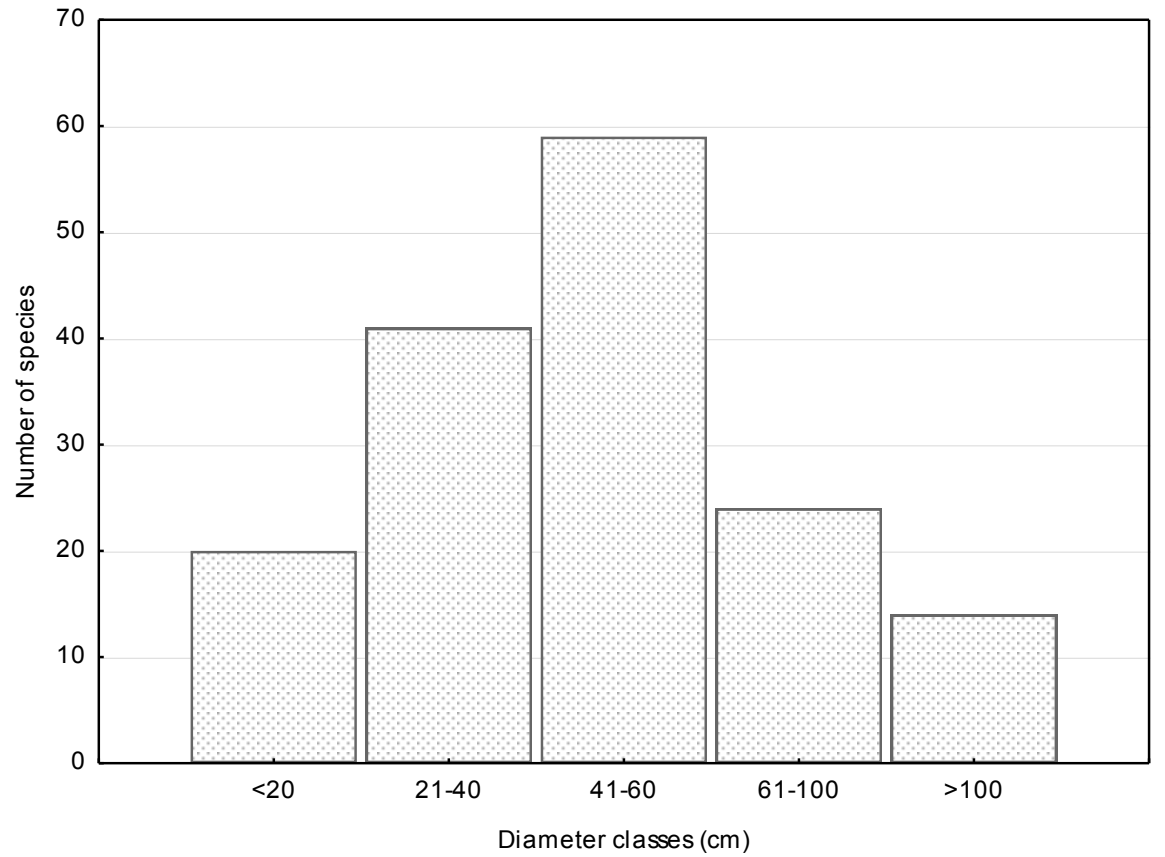

Figure 5. Number of lichens according to trunk diameter of Cedrus atlantica 


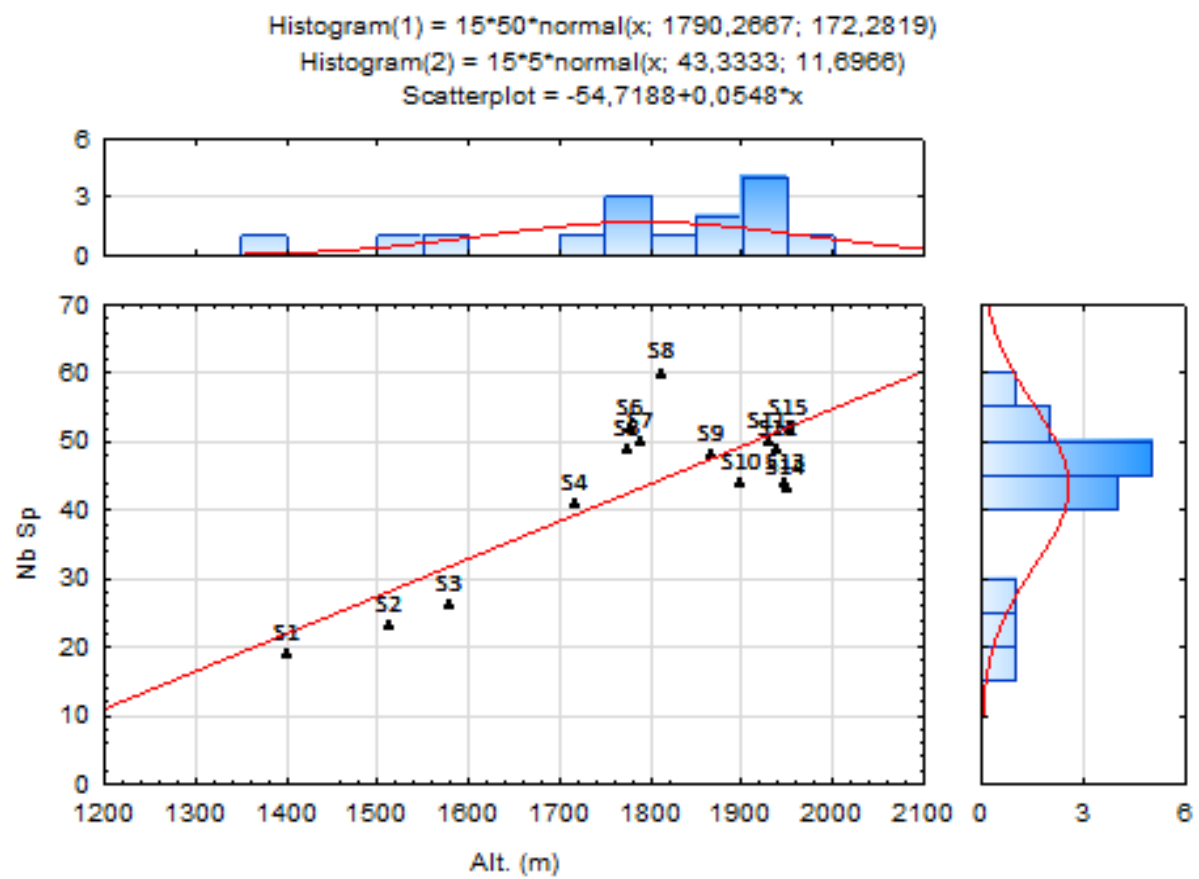

Figure 6. The relationship between the number of lichen species and altitude

Table 3. Sorensen Similarity Index between the 15 sites in Mount Babor Forest, Algeria

\begin{tabular}{|c|c|c|c|c|c|c|c|c|c|c|c|c|c|c|c|c|c|}
\hline & & S1 & S2 & S3 & S4 & S5 & S6 & S7 & S8 & S9 & S10 & S11 & S12 & S13 & S14 & S15 & \\
\hline \multirow{15}{*}{ 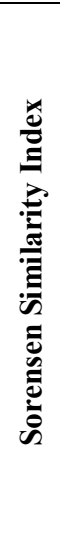 } & S1 & & 16 & 13 & 9 & 15 & 15 & 13 & 11 & 10 & 9 & 12 & 12 & 13 & 15 & 10 & \multirow{15}{*}{$\begin{array}{l}0 \\
0 \\
0 \\
0\end{array}$} \\
\hline & S2 & 0.76 & & 20 & 14 & 20 & 21 & 15 & 13 & 15 & 19 & 18 & 18 & 14 & 16 & 14 & \\
\hline & S3 & 0.57 & 0.81 & & 18 & 22 & 22 & 18 & 12 & 20 & 22 & 20 & 16 & 21 & 22 & 19 & \\
\hline & S4 & $\mathbf{0 . 3 0}$ & 0.43 & 0.53 & & 33 & 33 & 29 & 26 & 25 & 31 & 31 & 20 & 28 & 30 & 27 & \\
\hline & S5 & 0.42 & 0.53 & 0.56 & 0.70 & & 47 & 41 & 36 & 38 & 46 & 44 & 33 & 42 & 38 & 40 & \\
\hline & S6 & 0.43 & 0.57 & 0.57 & 0.72 & 0.92 & & 44 & 41 & 38 & 40 & 41 & 42 & 39 & 36 & 34 & \\
\hline & S7 & 0.32 & 0.36 & 0.41 & 0.57 & 0.73 & 0.8 & & 41 & 36 & 40 & 35 & 31 & 37 & 34 & 36 & \\
\hline & S8 & 0.32 & 0.36 & 0.32 & 0.58 & 0.72 & 0.83 & 0.75 & & 31 & 34 & 34 & 26 & 32 & 30 & 30 & \\
\hline & S9 & 0.31 & 0.44 & 0.57 & 0.58 & 0.79 & 0.80 & 0.69 & 0.67 & & 42 & 40 & 31 & 32 & 30 & 29 & \\
\hline & S10 & 0.26 & 0.52 & 0.57 & 0.68 & 0.90 & 0.80 & 0.72 & 0.69 & 0.89 & & 49 & 36 & 36 & 36 & 32 & \\
\hline & S11 & 0.35 & 0.5 & 0.53 & 0.68 & 0.87 & 0.82 & 0.64 & 0.53 & 0.86 & 0.98 & & 36 & 42 & 36 & 29 & \\
\hline & S12 & 0.38 & 0.53 & 0.45 & 0.47 & 0.68 & 0.89 & 0.59 & 0.55 & 0.7 & 0.76 & 0.77 & & 40 & 37 & 30 & \\
\hline & S13 & 0.36 & 0.73 & 0.53 & 0.6 & 0.80 & 0.76 & 0.66 & 0.58 & 0.66 & 0.70 & 0.83 & 0.83 & & 42 & 35 & \\
\hline & S14 & 0.48 & 0.48 & 0.63 & 0.71 & 0.73 & 0.92 & 0.66 & 0.65 & 0.68 & 0.77 & 0.78 & 0.85 & 0.88 & & 35 & \\
\hline & S15 & 0.29 & 0.38 & 0.5 & 0.6 & 0.79 & 0.68 & 0.66 & 0.61 & 0.79 & 0.64 & 0.59 & 0.64 & 0.69 & 0.76 & & \\
\hline
\end{tabular}

\section{Habitat similarity}

The Sorensen similarity index applied to epiphytic lichens revealed heterogeneity in the structure and community composition of the flora lichen of Mount Babor Forest. Similarity values ranged from 0.26 to 0.98 (Table $3)$. It is observed that the similarity is very high, with a coefficient of similarity greater than $90 \%$, for sites $10-11$ (98\%), it is $92 \%$ for sites 5-6 and 6-14 and 90\% for sites 510. These sites had the same types of forest habitat (topography and forest structure). Weak similarities $(<30 \%)$ were detected for sites $1-10(26 \%)$, it was $29 \%$ for sites $1-15$ and it was $30 \%$ for sites $1-4$.

\section{Discussion}

The Mount Babor Forest has rich epiphytic lichen diversity, despite the small area of the region studied.
Sixty-six species recorded on two phorophytes: Cedrus atlantica and Quercus faginea. Lichen richness in this study was higher compared to the lichen richness in other regions carried out on the genera of Cedrus and Quercus. Boutabia et al. (2018) reported 50 species in El Kala region (Algeria) on Quercus coccifera. Monia et al. (2017) reported 24 corticole taxa on $Q$. suber and $Q$. faginea in North East of Algeria. In Morocco, 47 taxa were identified on $C$. atlantica (Massari and Ravera, 2002). While in Turkey Cobanoglu and Sevgi (2009) identified 52 taxa on C. libani.

Among the lichens inventoried in the Mount Babor Forest, 16 species are protected by Algerian legislation (Executive Decree No. 12-03 of 4 January 2012). These are Anaptychia ciliaris, Evernia prunastri, Ramalina farinacea, Cladonia coniocraea, Cladonia fimbriata, 
Cladonia symphycarpa, Nephroma laevigatum, Parmelina tiliacea, Parmelina pastillifera, Phlyctis agelaea, Phlyctis argena, Physcia aipolia, Physcia leptalea, Physcia tenella, Physconia grisea, and Physconia venusta.

The physiognomic types of lichens in the study area were dominated by crustose and foliose thalli. On the other hand, the least represented categories were the squamular, gelatinous, and leprosy thalli. The same findings were obtained in Algeria by Rebbas et al. (2011) in Gouraya National Park (Béjaiia) and in Elkala National Park (Boutabia et al. 2015) as well as in Tunisia by El Mokni et al. (2015).

The lichen richness between the two phorophytes of Cedrus atlantica and Quercus faginea was different. Quercus faginea, which has a moderately acidic smooth bark tree, provides suitable habitat for the colonization of Collemaceae which prefers smooth bark, while C. atlantica is an acidic environment for epiphytes (Bricaud 2006; Hauck 2011). C. atlantica, with thick and rough bark, is mainly preferred by Parmeliaceae (11 species of lichens recorded). The same findings were reported in the Himalayas (Mishra and Upreti 2016). Nitrophilic lichen species have shown a significant decrease with altitude. The closure and aging of afforestation play a significant role in this decrease (Bricaud 2010).

A positive relationship between the number of epiphytic lichen species and the diameter of $C$. atlantica trees was notable in this study. This result is in line with similar recent studies reporting the effect of tree diameter on the distribution and composition of the number of lichen species (Johansson et al. 2007; Cobanoglu and Sevgi 2009). The correlation between lichen richness and tree diameter is probably due to chemical properties and physical changes in the bark of $C$. atlantica with age. Since the lichens grow very slowly and the colonization of species on the trees take many years, trees with diameters less than $20 \mathrm{~cm}$ are too young for the lichens to reach visible thalli (Snäll et al. 2003; Kantvilas and Jarman 2004; Nascimbene et al. 2009). Therefore, epiphytes appear to be more diverse on trunks with a diameter between 41 and 60 $\mathrm{cm}$. Likewise, Moning et al. (2009), found that high levels of lichen diversity were generally associated with large tree diameters. However, the number of species decreases again on old trees with large diameters $(\varnothing>100 \mathrm{~cm})$. Because, if the diameter of the tree increases, pieces of bark are replaced by new, smoother plates of bark. This, to a certain extent, favors the establishment of new lichen colonization (Cobanoglu and Sevgi 2009).

The number of lichen species is closely related to the altitudinal gradient. The highest number of species was observed in high altitude stations. The macro lichens (indicators of abundant humidity) such as representatives of the Collemataceae and Physciaceae families were infrequent in all stations but their proportion increases with altitude. This is mainly linked to climatic parameters (humidity, temperature, precipitation) (Normann et al. 2010; Bässler et al. 2016).

The diversity of forest species at high altitudes may also cause the richness in lichen biodiversity in the Mount Babor Forest. Our observations are in agreement with those of a study in northern Norway, where forest structure has been shown to be a richness for macro lichen communities (Werth et al. 2005). On the other hand, Moning et al. (2009) showed that in the Bavarian Forest National Park in southeastern Germany, the effects of forest structure as a defining characteristic of habitat have no effect on lichen biodiversity.

The decline of lichen species in low altitudes can also be caused by anthropogenic activities, such as overgrazing, deforestation, and overexploitation. This adds the indirect effects of atmospheric pollution, caused by serious annual and repeated fires (Eversman 2001; Quezel and Médail 2003). A study carried out in the coniferous forests of Sierra Nevada and the Warner Mountains of California by Miller et al. (2018) suggested that fires can lead to significant losses of lichen biodiversity. Recent studies in Brazil, and the Amazonian forests, have shown the decline in the diversity of tropical lichens and that many of these species disappear under disturbance (Flakus 2013; Plata and Lucking 2013; Cáceres et al. 2017).

In conclusion, the study of epiphytic lichens in the Mount Babor Forest resulted in the identification of 66 species belonging to 24 families and 38 genera. Morphological types (crustose and foliose) were the most common in the study area. A distinct relationship between the parameters (i.e., tree diameter and altitude) and the specific lichen richness has been established. The altitude favors the increase in the number of epiphytic species. The Sorensen similarity index revealed heterogeneity in the structure and community composition of epiphytic lichen vegetation between all the sites studied.

\section{REFERENCES}

Amrani S, Nacer A, Noureddine NE, Seaward MRD. 2015. Lichenological exploration of Algeria: historical overview and annotated bibliography, 1799-2013. Willdenowia 45 (1): 15-34.

Bässler C, Cadotte MW, Beudert B, Heibl C, Blaschke M, Bradtka JH, Werth S Müller, J. 2016. Contrasting patterns of lichen functional diversity and species richness across an elevation gradient. Ecography 39 (7): 689-698.

Benítez A, Aragón G, González Y, Prieto M. 2018. Functional traits of epiphytic lichens in response to forest disturbance and as predictors of total richness and diversity. Ecol Indicat 86: 18-26. DOI: 10.1016/j.ecolind.2017.12.021.

Bergamini A, Scheidegger C, Stofer S, Carvalho P, Davey S, Dietrich M, Keller C. 2005. Performance of macrolichens and lichen genera as indicators of lichen species richness and composition. Conserv Biol 19 (4): 1051-1062. DOI: 10.1111/j.1523-1739.2005.00192.x-i1.

Boistel A. 1986. Nouvelle flore des lichens: pour la détermination facile des espèces aves 1178 figures inédites, représentant toutes les espèces de France et les espèces communes d'Europe. Belin. [French]

Boni S, Yorou NS. 2015. Diversité et variabilité inter-ethniques dans la consommation de champignons sauvages de la région de N'Dali au Bénin. Tropicultura 33 (4): 266-276. [French]

Bougaham AF, Bouchibane M, Véla E. 2015. Inventaire des orchidées de la Kabylie des Babors (Algérie), éléments de cartographie et enjeux patrimoniaux. Journal Europäischer Orchideen 47(1): 89. [French]

Bougaham AF, Rebbas K. 2020. Nouvelle station de Cephalanthera rubra (Orchidaceae) au Babor (nord-est de l'Algérie) New station of Cephalanthera rubre (Orchidaceae) in Babor (northeastern Algeria). Bulletin de la Société Royale des Sciences de Liège 89: 115-122. [French]

Bougaham AF, Rebbas K, Vela E. 2020. Découverte d'Epipactis microphylla (Orchidaceae) au Mount Babor (nord-est de l'Algérie), 
orchidée nouvelle pour l'Afrique du Nord. Fl. Medit. 30: 261-271. [French]

Boutabia L, Telailia S, de Belair, G. 2015. Corticolous lichen flora on Quercus suber L. in the wetlands of El Kala national park (NorthEastern Algeria). Adv Environ Biol 9 (4): 360-372.

Boutabia L, Telailia S, Slimani A, Mokni RE. 2018. Diversity of epiphytic lichen flora of kermes oak formations (Quercus coccifera) from the El kala littoral (extreme northeastern Algeria). J New Sci Agric Biotechnol 7: 3299-3307.

Bricaud O. 2006. Aperçu de la végétation lichénique du site de Saint Daumas (Var). Association française de lichénologie 64 http://www.foretsanciennes.fr/wp-content/uploads/Bricaud-2006Lichens.pdf [French]

Bricaud O. 2010. Les lichens des forêts de la région méditerranéenne française et leur relation avec la continuité écologique des boisements. Rapport WWF-AFL, Marseille, 118p, Ecologie des lichens et de leurs groupements en milieu forestier $7 \mathrm{p}$. $\mathrm{http}: / /$ www.foretsanciennes.fr/wpcontent/uploads/Bricaud_2010_BD.pdf [French]

Cobanoglu G, Sevgi O. 2009. Analysis of the distribution of epiphytic lichens on Cedrus libani in Elmali Research Forest (Antalya, Turkey). J Environ Biol 30 (2), 205-212.

Da Silva Cáceres ME, Aptroot A, Lücking R. 2017. Lichen fungi in the Atlantic rain forest of Northeast Brazil: the relationship of species richness with habitat diversity and conservation status. Braz J Bot 40 (1): 145-156. DOI 10.1007/s40415-016-0323-6

Journal Officiel De La Republique Algerienne Democratique, Décret exécutif no 12-03 du 10 Safar 1433 correspondant au 4 janvier 2012 fixant la liste des espèces végétales non cultivées protégées. https://www.joradp.dz/FTP/JO-FRANCAIS/2012/F2012003.pdf

El Mokni R, Boutabia L, Sebei H, El-Aouni MH. 2015. Species richness, distribution, bioindication and ecology of lichens in oak forests of Kroumiria, North West of Tunisia. J Bio Env Sci 7 (2): 32-60.

Eversman S. 2001. Recolonization of substrates burned in the 1988 Yellowstone park fires by cryptogams (Lichens, Mosses, and Fungi). The UW National Parks Service Research Station Ann Rep 25: 113118. DOI: $10.13001 /$ uwnpsrc. 2001.3471

Flakus A. 2013. Foliicolous lichenized fungi of lowland Amazon forests in Pando, Bolivia. Polish Bot J 58 (2): 539-554.

Gauslaa Y. 2014. Rain, dew, and humid air as drivers of morphology, function and spatial distribution in epiphytic lichens. The Lichenologist 46 (1): 1-16. DOI: 10.1017/S0024282913000753.

Gharzouli R. 2007. Flore et végétation de la kabylie des babors : étude floristique et phytosociologique des groupements forestiers et postforestiers des djebels Takoucht, Adrar ou-Mellal, Tababort et Babor [Dissertation]. Univ. Sétif, Setif, Algeria. [French]

Hauck M. 2011. Site factors controlling epiphytic lichen abundance in northern coniferous forests. Fuel Energ Abstr 206 (2): 81-90.

Hedenas H, Ericson L. 2000. Epiphytic macro lichens as conservation indicators: successional sequence in Populus tremula stands. Biol Conserv 93 (1): 43-53. DOI: 10.1016/S0006-3207(99) 00113-5

Jans HM. 2011. Guide des fougères, mousses et lichens d'Europe, Ed. Delachaux et Niestlé. [French]

Johansson P, Rydin H, Thor G. 2007. Tree age relationships with epiphytic lichen diversity and lichen life history traits on ash in southern Sweden. Ecoscience 14 (1): 81-91. DOI: 10.2980/11956860(2007)14[81:TARWEL]2.0.CO;2.

Jonsson BG, Jonsell M. 1999. Exploring potential biodiversity indicators in boreal forests. Biodiversity and Conservation 8 (10): 1417-1433. DOI: /10.1023/A:1008900309571.

Kantvilas G, Jarman SJ. 2004. Lichens and bryophytes on Eucalyptus obliqua in Tasmania: management implications in production forests Biol Conserv 117 (4): 359-373. DOI: /10.1016/j.biocon.2003.08.001

Ledant JP. 1981. Conservation et fragilité de la forêt de Babor, habitat de la Sittelle kabyle. Aves18: 1-9. [French]

Ledant JP, Jacobs P, Ochando B, Renault J. 1985. Dynamique de la Forêt du Mont babor et préférences écologiques de la sittelle kabyle Sitta ledanti. Biol Conserv 32 (3): 231-254.

Łubek A, Kukwa M, Jaroszewicz B, Czortek P. 2018. Changes in the epiphytic lichen biota of Białowieża Primeval Forest are not explained by climate warming. Sci Total Environ 643: 468-478. DOI: 10.1016/j.scitotenv.2018.06.22

Massari G, Ravera S. 2002. Epiphytic lichen vegetation of the Cedrus atlantica forests (Morocco). Ecologia Mediterranea 28 (2): 51-57. DOI: $10.3406 /$ ecmed.2002.1573
Miller JE, Root HT, Safford HD. 2018. Altered fire regimes cause long- term lichen diversity losses. Global Change Biol 24 (10): 49094918. DOI: $10.1111 / \mathrm{gcb} .14393$.

Mishra GK, Upreti DK. 2016. Diversity and distribution of macro-lichen in Kumaun Himalaya, Uttarakhand. Intl J Adv Res 4 (2): 912-925.

Mohamed AH, Miara MD, Rebbas K, Slimani A, Ravera S, Hamer EAS. 2014. Mise à jour de l'inventaire des lichens d'Algérie. Revue Ecologie-Environment 10: 75-103. [French]

Monia AA, Rafika B, Tarek H. 2017. Lichen diversity in the Edough Peninsula, North East of Algeria. Bot Complut 42 (2018): 9-18. DOI: 10.5209/BOCM.61381

Moning C, Werth S, Dziock F, Bässler C, Bradtka J, Hothorn T, Mueller J. 2009. Lichen diversity in temperate montane forests is influenced by forest structure more than climate. For Ecol Manag 258 (5): 745751. DOI: $10.1016 /$ j.foreco.2009.05.015.

Nardi P, Di Matteo G, Palahi M, Scarascia MG. 2016. Structure and evolution of Mediterranean forest research: a science mapping $\begin{array}{llllll}\text { approach. PloS One } 11 & \text { (5): e0155016. DOI: }\end{array}$ 10.1371/journal.pone.0155016.

Nascimbene J, Marini L, Motta R, Nimis PL. 2009. Influence of tree age, tree size and crown structure on lichen communities in mature Alpine spruce forests. Biodiv Conserv 18 (6): 1509. DOI: 10.1007/s10531008-9537-7.

Normann F, Weigelt P, Gehrig-Downie C, Gradstein SR, Sipman HJ, Obregon A, Bendix J. 2010. Diversity and vertical distribution of epiphytic macro lichens in lowland rain forest and lowland cloud forest of French Guiana. Ecol Indicat 10 (6): 1111-1118. DOI: 10.1016/j.ecolind.2010.03.008.

Ozenda P, and Clauzade G. 1970. Les lichens. Etude biologique et flore illustrée. Ed. Masson et Cie. Paris, France. [French]

Pinho P, Bergamini A, Carvalho P, Branquinho C, Stofer S, Scheidegger C, Maguas C. 2012. Lichen functional groups as ecological indicators of the effects of land-use in Mediterranean ecosystems. Ecol Indicat 15 (1): 36-42DOI: 10.1016/j.ecolind.2011.09.022

Plata ER, Lücking R. 2013. High diversity of Graphidaceae (lichenized Ascomycota: Ostropales) in Amazonian Perú. Fungal Diversity 58 (1): 13-32. DOI: $10.1007 / \mathrm{s} 13225-012-0172-\mathrm{y}$.

Quézel P, Santa S. 1962. Nouvelle flore de l'Algérie et des régions désertiques méridionales, T1. Paris. [French]

Quézel P, Médail F. 2003. Que faut-il entendre par" forêts méditerranéennes. Forêt méditerranéenne 24 (1): 11-31. [French]

Radies DN, Coxson DS. 2004. Macro lichen colonization on 120-140 year old Tsuga heterophylla in wet temperate rainforests of centralinterior British Columbia: a comparison of lichen response to evenaged versus old growth stand structures. Lichenologist 36 (3-4): 235247. DOI: $10.1017 /$ S0024282904014227.

Rebbas K, Boutabia L, Touazi Y, Gharzouli R, Djellouli Y, Alatou, D. 2011. Inventaire des lichens du Parc national de Gouraya (Béjaïa, Algérie). Phytothérapie 9 (4): 225. DOI: 10.1007/s10298-011-0628-3. [French]

Sanogo S, Kabre TJ. 2014. Dynamique de structuration spatio-temporelle des populations de familles de macroinvertébrés dans un continuum lac de barrage-effluent-fleuve issu de périmètre irrigué. Bassin de la Volta (Burkina Faso). J Appl Biosci 78: 6630-6645. DOI: 10.4314/jab.v78i1.9. [French]

Scheidegger C, Goward T. 2002. Monitoring lichens for conservation: red lists and conservation action plans. Monitoring with LichensMonitoring Lichens. Springer, Dordrecht. DOI: 10.1007/978-94-0100423-7 12

Sevgi O, Cobanoglu G, Sevgi E. 2010. Investigation of lichen populations and their similarity analysis in Serif Yuksel Forest, Turkey. J Environ Biol 31 (1): 135.

Snäll T, Ribeiro JRPJ, Rydin H. 2003. Spatial occurrence and colorizations in patch- tracking metapopulations: local conditions versus dispersal. Oikos 103 (3): 566-578. DOI: $10.1034 / \mathrm{j} .1600$ 0706.2003.12551.x

Sorensen TA. 1948. A method of establishing groups of equal amplitude in plant sociology based on similarity of species content and its application to analyses of the vegetation on Danish commons. Biol Skar 5: 1-34.

Soto Medina E, Lücking R, Bolaños Rojas, A. 2012. Phorophyte specificity and microenvironmental preferences of corticolous lichens in five phorophyte species from premontane forest of Finca Zíngara, Cali, Colombia. Revista de Biologia Tropical 60 (2): 843-856. 
Stapper NJ, John V. 2015. Monitoring climate change with lichens as bioindicators. Poll Atmospheric 22: 2268-3798. DOI: 10.4267 /pollution-atmospherique. 4936

Stofer S, Bergamini A, Aragon G, Carvalho P, Coppins BJ, Davey S, Lökös L. 2006. Species richness of lichen functional groups in relation to land use intensity. The Lichenologist 38 (4): 331-353. DOI: DOI: 10.1017/S0024282906006207

Tiévant P. 2001. Guide des lichens: 350 espèces de lichens d'Europe. Delachaux et Niestlé. .France. [French]

Van Haluwyn C, Asta J, Gavériaux JP. 2013. Guide des lichens de France. Lichens des arbres. Belin. [French]

Van Herk CM. 2001. Bark pH and susceptibility to toxic air pollutants as independent causes of changes in epiphytic lichen composition in space and time. Lichenologist 33 (5): 419-441. DOI: 10.1006/lich.2001.0337
Van Stan II, JT, Pypker TG. 2015. A review and evaluation of forest canopy epiphyte roles in the partitioning and chemical alteration of precipitation. Sci Total Environ 536, 813-824.

Vondrák J, Malíček J, Palice Z, Bouda F, Berger F, Sanderson N., Acton A, Pouska V, Kish, R. 2018. Exploiting hot spots; effective determination of lichen diversity in a Carpathian virgin forest. PLoS One 13 (9): e0203540. DOI: 10.1371/journal.pone.0203540.

Watt AD, Bradshaw RHW, Young J, Alard D, Bolger T, Chamberlain D, Johnson R. 2007. Trends in biodiversity in Europe and the impact of land use change. Biodiversity under Threat. Issues Environ Sci Technol 25: 135-160.

Werth S, Tømmervik H, Elvebakk A. 2005. Epiphytic macro lichen communities along regional gradients in northern Norway. J Veg Sci 16 (2): 199-208. DOI: 10.1111/j.1654-1103.2005.tb02356.x.

Whittaker RH. 1960. Vegetation of the Siskiyou Mountains, Oregon and California. Ecol Monogr 30 (3): 279-338. DOI: 10.2307/1943563. 


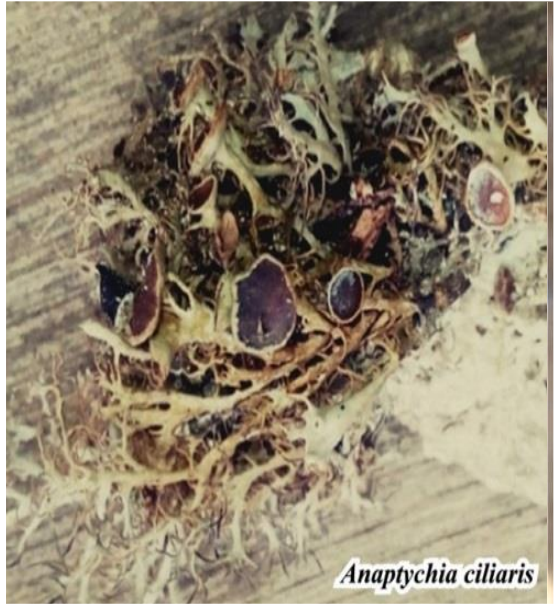

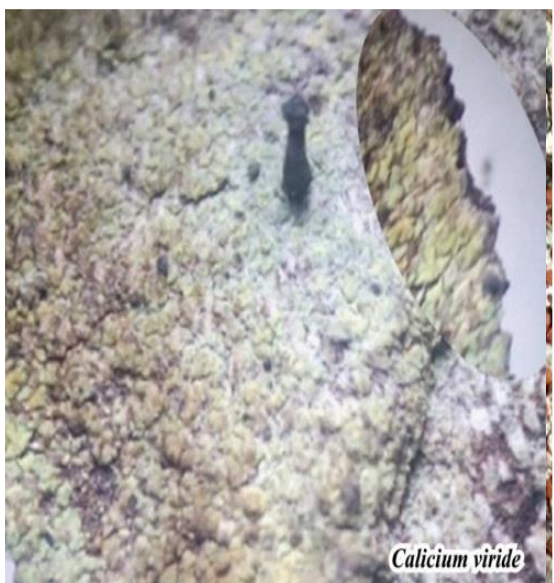
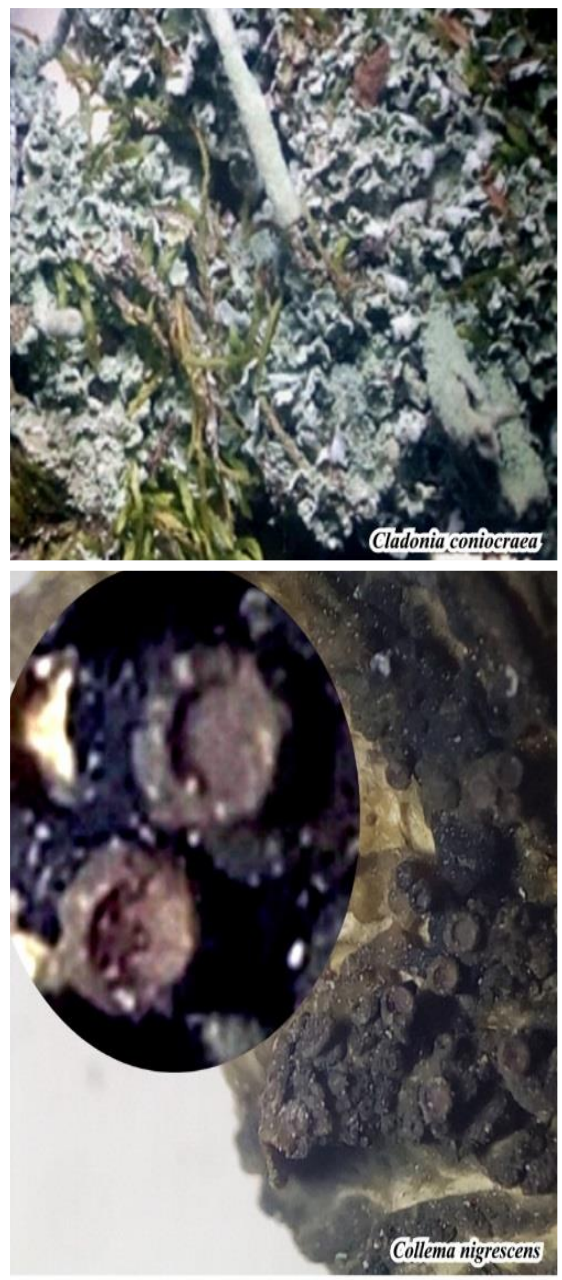
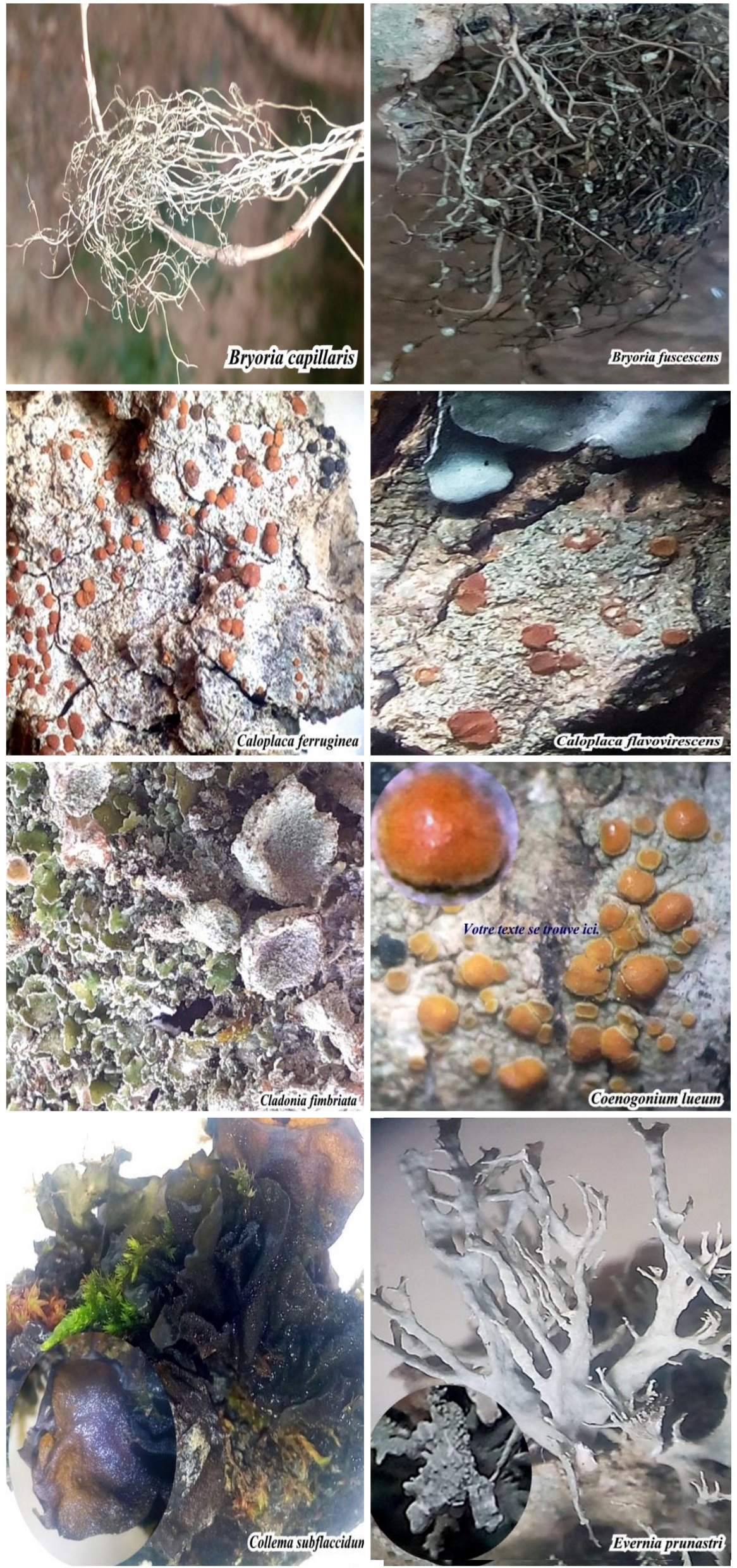

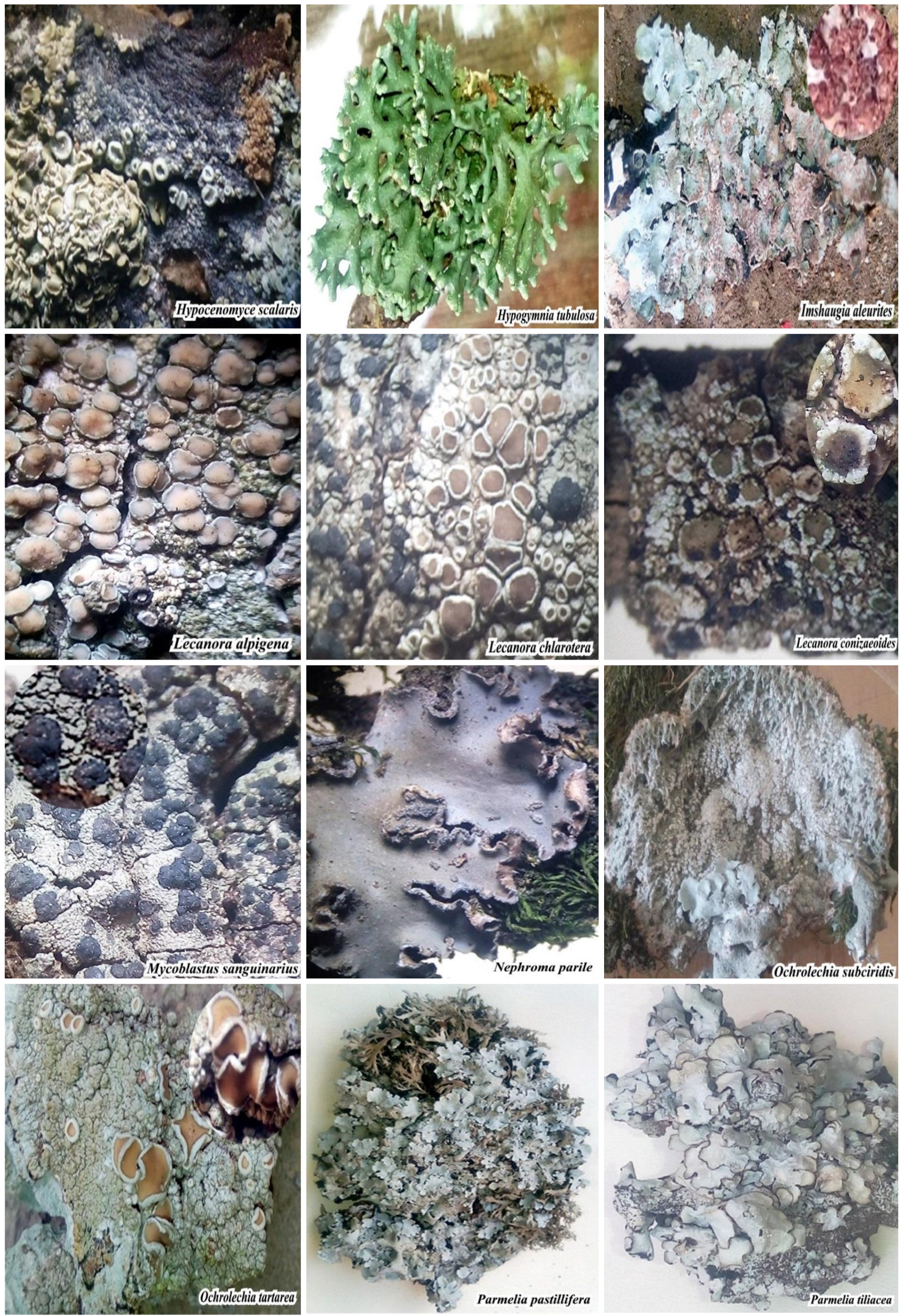

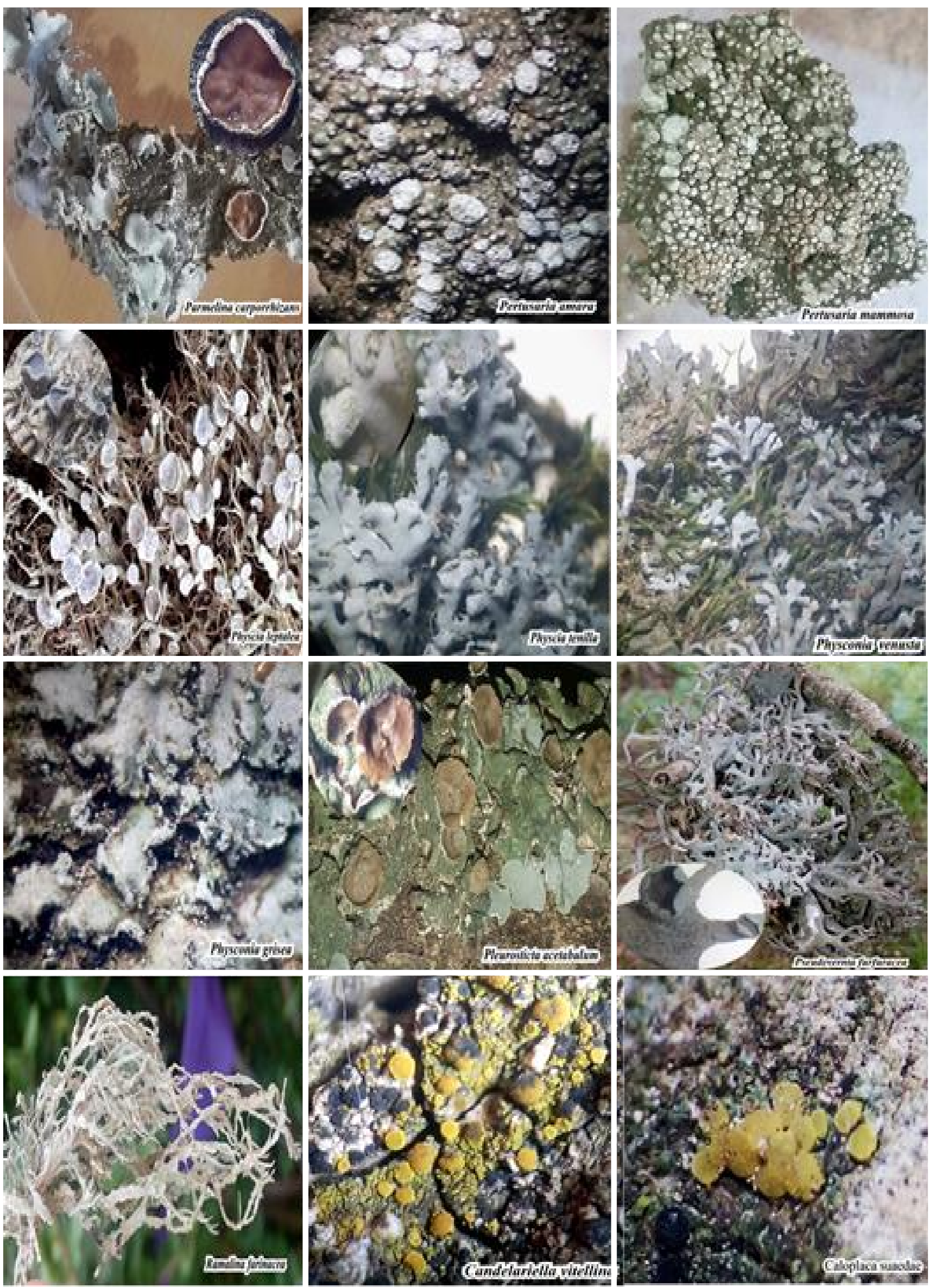

Figure S1. Some lichen species in Mount Babor Forest, Algeria 